\title{
Circulating activin A during equine gestation and immunolocalization of its receptors system in utero-placental tissues and fetal gonads
}

\author{
Pramod DHAKAL ${ }^{1-3 \#}$, Nobuo TSUNODA ${ }^{4 \#}$, Yasuo NAMBO ${ }^{2,5}$, Hiroyuki TANIYAMA ${ }^{6}$, \\ Kentaro NAGAOKA ${ }^{1,2,7}$, Gen WATANABE ${ }^{1,2,7}$ and Kazuyoshi TAYA ${ }^{1,4 *}$ \\ ${ }^{1}$ Laboratory of Veterinary Physiology, Cooperative Department of Veterinary Medicine, Faculty of Agriculture, Tokyo \\ University of Agriculture and Technology, Tokyo 183-8509, Japan \\ ${ }^{2}$ United Graduate School of Veterinary Sciences, Gifu University, Gifu 501-1 193, Japan \\ ${ }^{3}$ Division of Animal Science, University of Missouri, MO 65211, U.S.A. \\ ${ }^{4}$ Shadai Corporation, Hokkaido 059-1432, Japan \\ ${ }^{5}$ Department of Veterinary Medicine, Obihiro University of Agriculture and Veterinary Medicine, Hokkaido \\ 080-8555, Japan \\ ${ }^{6}$ Department of Veterinary Pathology, Rakuno Gakuen University, Hokkaido 069-8501, Japan \\ ${ }^{7}$ Cooperative Division of Veterinary Sciences (Doctoral Program), Graduate School of Agriculture, Tokyo University \\ of Agriculture and Technology, Tokyo 183-8509, Japan
}

Although equine gestation is unique from the standpoint of fetal gonadal enlargement and regression, the activator of this process is still unknown. The present study aimed to show a possible role of activin during equine gestation. In the first experiment, weekly plasma samples from six pregnant mares were used to measure activin $A$. In the second experiment, eight pregnant mares carrying female (gestational days 110, 140, 180, and 270) and male fetuses (gestational days 120,180, 225, and 314) were used for immunohistochemistry of activin receptors (IA, IB, IIA, IIB), and their intracellular mediators (Smad2, Smad3, Smad4). Activin A levels in maternal circulation remained low until fourth weeks of gestation, thereafter, started to increase, and peaked first at 11 weeks of gestation. The second significant peak was observed on the day of parturition. Activin receptors type IA, $I B, I I A$, and IIB were immunostained in interstitial and germ cells of fetal ovaries and testes along with utero-placental tissues. Smad2, Smad3, and Smad4 were also immunolocalized in all these organs. These results demonstrated the activin-producing capacity of uteroplacental tissues, and also evidenced the existence of activin receptors and functional signaling molecules in these organs. The first increment in circulating activin A in maternal circulation coinciding with the timing of initiation of fetal gonadal enlargement suggests that activin from the utero-placental tissues may have a stimulatory role in fetal gonad enlargement and utero-placental development in mares, whereas the second peak could be important to follicular development in the maternal ovary for foal heat.

Key words: activin, activin receptor, fetal gonad, placenta, pregnant mare

Received: December 18, 2019

Accepted: April 19, 2021

*Corresponding author. e-mail: taya@cc.tuat.ac.jp

\#These authors contributed equally to this work.

(C2021 Japanese Society of Equine Science

This is an open-access article distributed under the terms of the Creative Commons Attribution Non-Commercial No Derivatives (by-nc-nd) License. (CC-BY-NC-ND 4.0: https://creativecommons.org/licenses/ by-nc-nd/4.0/)

\author{
J. Equine Sci. \\ Vol. 32, No. 2 \\ pp. 39-48, 2021
}

The equine fetal gonads of both sexes display a unique phenomenon of remarkable enlargement of their size resulting from an increased number and hypertrophy of interstitial cells [37]. It is well established that the size of the equine fetal gonads during the second half of gestation is larger than that of the maternal ovaries [4, 34, 35]. Although the mechanism and physiological significance of this enlargement of fetal gonads are not clear, a previous 
study showed that gonadectomy in the equine fetus affected fetal development [28]. To clarify the mechanism responsible for enlargement of fetal gonads during gestation, a key hormone, "activin," was selected as a candidate in the present study.

Activins, which belong to the transforming growth factor beta (TGF- $\beta$ ) superfamily, were initially isolated from porcine follicular fluid and characterized by their capacity to stimulate the secretion of follicle-stimulating hormone (FSH) from pituitary cell cultures $[17,40,42]$. The activins are homo- and heterodimers of the $\beta_{\mathrm{A}}$ and $\beta_{\mathrm{B}}$ subunits which are linked by a single covalent disulfide bond, forming different isoforms like activin $A\left(\beta_{A} \beta_{A}\right)$, activin $\mathrm{B}\left(\beta_{\mathrm{B}} \beta_{\mathrm{B}}\right)$ and activin $\mathrm{AB}\left(\beta_{\mathrm{A}} \beta_{\mathrm{B}}\right)$. Activins mediate their actions by binding to a complex of transmembrane serine and threonine kinase receptors [27]. These activin receptors can be classified into two main categories, namely the type II receptor group (ActR IIA or ActR IIB), and the type I receptor group (ActR IA and ActR IB) [20]. The activins can bind to their individual type II receptor (IIA or IIB) when expressed alone but fail to bind to the type I receptor in the absence of the type II receptor [27, 36]. However, both receptor types are necessary to generate a high-affinity complex with activin for its intracellular signaling $[40,41]$. The activated activin type I receptor propagates the signal through the phosphorylation of other cytoplasmic coactivators (Smad2 and $S m a d 3)$ proteins which then interact with common Smad4. The activated Smad2/4 or Smad3/4 complex, which translocates to the cell nucleus, acts as the transcription factor for target genes of activin signaling $[18,41]$.

At present, the roles of activin are known to be diverse, including cell proliferation, differentiation, apoptosis, metabolism, homeostasis, immune response, wound repair, and endocrine function [3]. The involvement of activins in equine reproduction is evident from several experiments that demonstrated the immunolocalization of activin $\beta_{\mathrm{A}}$, and $\beta_{\mathrm{B}}$ subunits in fetal gonads $[34,35]$ and $\beta_{\mathrm{A}}$ subunit in the endometrium [2] and subsequent evidence of mRNA for the $\beta_{\mathrm{A}}$ subunit in the endometrium [44] and fetal gonads $[34,35]$. Further evidence comes from an experiment that detected the activin A subunit in the dominant follicle [24].

The plasma concentrations of activin have not yet been characterized in pregnant mares. Although the activin subunit proteins have been demonstrated in the equine fetal gonads and placenta, there is no information on whether the receptors and signaling molecules for activin exist in these tissues or not. The objectives of this study were to 1) measure the activin A concentrations in the circulation of pregnant mares and 2) perform immunostaining for the activin receptors and their intracellular mediators in the equine fetal gonads (testes and ovaries) and utero-placental tissues to investigate the ontogeny of activin production during the period of accelerated growth of the equine fetal gonads.

\section{Materials and Methods}

\section{Animals}

In the first experiment, six 4- to 7-year-old pregnant Thoroughbred mares, were used for blood collection. Weekly blood samples were collected from the day of mating (March 30 to May 1) until a week after the day of foaling (March 2 to April 4) via the jugular vein into sterile heparinized vacutainers at 1300-1400 hr. Blood samples were also collected on the day of parturition. Plasma was harvested and stored at $-20^{\circ} \mathrm{C}$ until assayed. The mean duration of gestation was $340.3 \pm 1.6$ days (mean \pm SEM, $n=6$ ).

In the second experiment, four normal Thoroughbred mares carrying female fetuses at gestational days 110, 140, 180 , and 270 and four normal Thoroughbred mares carrying male fetuses at gestational days $120,180,225$, and 314 , were used for immunohistochemistry of activin receptors (IA, IB, IIA, and IIB), and Smad2, Smad3, and Smad4. Female ( $\mathrm{n}=4$; gestational days $110,140,180$, and 270$)$ and male ( $\mathrm{n}=4$; gestational days $120,180,225$, and 314 ) fetuses and placentae were recovered from the pregnant Thoroughbred mares after euthanasia. The final day of mating was designated as Day 0 of gestation. The pregnant mares, which all had serious injuries, were euthanized with an overdose of a mixture of thiopental sodium (Mitsubishi Tanabe Pharma Corp., Osaka, Japan) and suxamethonium chloride (Astellas Pharma Inc., Tokyo, Japan) after intravenous administration of medetomidine (Nippon Zenyaku Kogyo Co., Ltd., Fukushima, Japan), prior to tissue recovery. All mares used in this experiment were reared in Hokkaido, Japan. All procedures were carried out in accordance with the guidelines on the use of horses established by Rakuno Gakuen University.

\section{Immunohistochemistry}

The fetal gonad samples containing both ovaries (gestational days 110, 140, 180, and 270) and testes (gestational days $120,180,225$, and 314) were fixed in freshly prepared $4 \%$ (w/v) paraformaldehyde (MilliporeSigma, St. Louis, MO, U.S.A.) in $0.01 \mathrm{M}$ PBS and embedded in paraffin. For immunohistochemistry, $6 \mu \mathrm{m}$-thick tissue sections were prepared. These sections were placed on glass slides coated with 3-aminopropyltriethoxysilane.

Goat polyclonal antibodies against activin receptors IA (AF637) and IIB (AF339) were purchased from R\&D Systems (Minneapolis, MN, U.S.A.). Goat polyclonal antibody against activin receptor IB; rabbit polyclonal antibody against Smad2 (ab63576), Smad3 (ab28379), and activin receptor IIA (ab71521); and rabbit monoclonal antibody 
against Smad4 (ab40759) were purchased from Abcam (Cambridge, U.K.). The antibodies against activin receptors IIB, IIA, IB, and IA were directed against the extracellular domains of recombinant human activin receptors IIB, IIA, IB, and IA, respectively. The antibodies against Smad2, Smad3, and Smad4 were directed against the synthetic Smad2 around the phosphorylation site of serine 467 (C-SS-M-S), a synthetic peptide of Smad3 corresponding to amino acids 192-21, and a synthetic peptide corresponding to Smad4 C-terminus, respectively, which were all of human origin.

Sections were deparaffinized with a graded alcohol series $(100,95$, and $70 \%$ ethanol), and rinsed in tap water, and endogenous peroxidase activity was quenched with $0.3 \%$ $\mathrm{H}_{2} \mathrm{O}_{2}$ in methanol. They were then processed for antigen retrieval by autoclaving at $121^{\circ} \mathrm{C}$ for $15 \mathrm{~min}$ in the presence of antigen unmasking solution (Vector Laboratories, Burlingame, CA, U.S.A.). Slides were rinsed in PBS and blocked with appropriate sera for $20 \mathrm{~min}$ at $20^{\circ} \mathrm{C}$. After blocking, they were incubated with a primary antibody overnight at $4{ }^{\circ} \mathrm{C}$. The primary antibodies were diluted in PBS. The primary antibodies for activin receptor IIA and IIB were diluted at the concentrations of 5 and $15 \mu \mathrm{g} / \mathrm{m} l$, respectively, and the rest of the primary antibodies were diluted at the concentration of $10 \mu \mathrm{g} / \mathrm{ml}$. After incubation with the primary antibody, slides were rinsed for $5 \mathrm{~min}$ in PBS and incubated with a biotinylated second antibody for 30 min prior to incubation with $\mathrm{ABC}$ reagent for $30 \mathrm{~min}$ using a Vectastain $\mathrm{ABC}$ detection kit (Vector Laboratories). The antigen-antibody complexes were then visualized by staining with an AEC Chromogen Kit (Boster Biological Technology, Inc., Fremont, CA, U.S.A.) for 5 min. Slides were counterstained with hematoxylin for $2 \mathrm{~min}$ and mounted in Mount-Quick Aqueous (Daido Sangyo Co., Ltd., Tokyo, Japan). As a control, sections were processed for immunohistochemistry with the omission of the primary antibody.

\section{Hormone assay}

Concentrations of activin A in plasma were measured by a sandwich enzyme-linked immunosorbent assay (ELISA) kit (DAC00B, R\&D Systems, Minneapolis, MN, U.S.A.). Concentrations of activin A were expressed in terms of recombinant human activin $\mathrm{A}$. The intra- and inter-assay coefficients of variation were 2.3 and $7.1 \%$, respectively.

\section{Statistical analysis}

The concentrations of activin A were expressed as means \pm SEM. One-way ANOVA, with Tukey's multiple comparison tests at $P<0.05$, was performed to detect significant changes in the plasma concentration of activin A during different stage of gestation.

\section{Results}

\section{Characterization of the activin A ELISA kit}

Displacement curves obtained with the two activin preparations from the equine placental tissues homogenates and ovarian follicular fluid are shown in Fig. 1. Competition between the labeled and unlabeled antigens in the equine placental tissues homogenates and ovarian follicular fluid produced excellent dose-response curves in the assays with the activin A ELISA kit. Each curve was reliably parallel to the respective standard curve, indicating that it was possible to measure the concentration of activin $\mathrm{A}$ in mares using this kit. These results also clearly demonstrated that equine placental tissues homogenates and ovarian follicular fluid contained large amounts of activin A.

\section{Changes in circulating activin A during gestation}

The circulating activin A concentrations during gestation, on the day of parturition, and one week after parturition are shown in Fig. 2. The plasma concentrations of activin A in the pregnant mares were low, at their basal levels, until the fourth week $(44.55 \pm 12.51 \mathrm{pg} / \mathrm{m} l)$ of gestation. They then started to increase and reached a significantly higher level $(91.60 \pm 15.91 \mathrm{pg} / \mathrm{m} l)$ at 11 weeks of gestation; they subsequently remained at fairly similar levels and reached a significantly high level $(298.56 \pm 38.67 \mathrm{pg} / \mathrm{m} l)$ again on the day of parturition. One week after parturition, the plasma concentrations of activin A dropped abruptly $(45.58 \pm 13.90$ $\mathrm{pg} / \mathrm{m} l$ ), and it was comparable to the basal levels observed before gestation (Fig. 2).

\section{Immunohistochemistry}

The results for the immune-localization of the activin receptors (IA, IB, IIA, IIB) and their intracellular mediators (Smad2, Smad3, Smad4) in the fetal gonads and placental tissues are summarized in Tables 1 and 2. In addition, representative results for the immunolocalization of the activin receptors and their intracellular mediators in fetal ovaries, testes, and placental tissues at 180 days of gestation are shown in Figs. 3 and 4.

\section{Immuno-localization of activin receptors IA, IB, IIA, and IIB}

All types of activin receptors were immunolocalized in germ cells and interstitial cells of the fetal ovary at 110 , 140,180 , and 270 days of gestation (Table 1) and those of the fetal testis at $120,180,225$, and 314 days of gestation (Table 2). The fetal ovary and testis were largely a mass of interstitial cells. The expression patterns of the four types of activin receptors in germ cells and interstitial cells of fetal ovaries (110, 140, 180, and 270 days of gestation) and fetal testes $(120,180,225$, and 314 days of gestation) did 


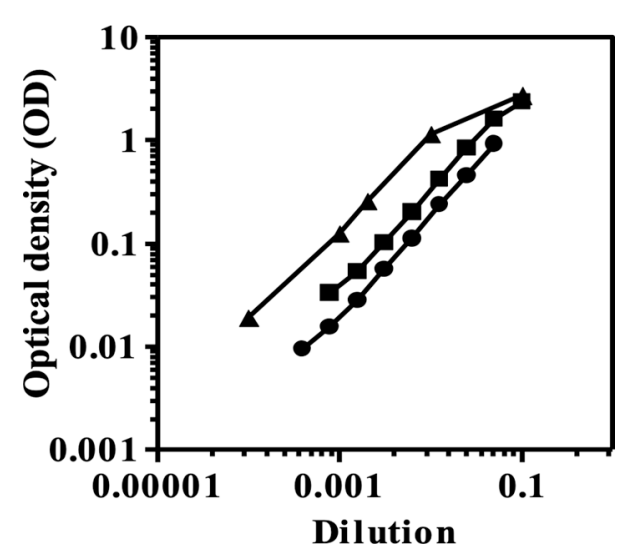

Fig. 1. Validation of the activin A enzyme-linked immunosorbent assay (ELISA) system for equine samples. Different dilutions of equine placental tissue homogenates $(\boldsymbol{\Delta})$ and equine follicular fluid (-) produced dose-response curves that were parallel to the standard curve $(\bullet)$ produced with recombinant activin A. Each value represents the mean of triplicate determinations.

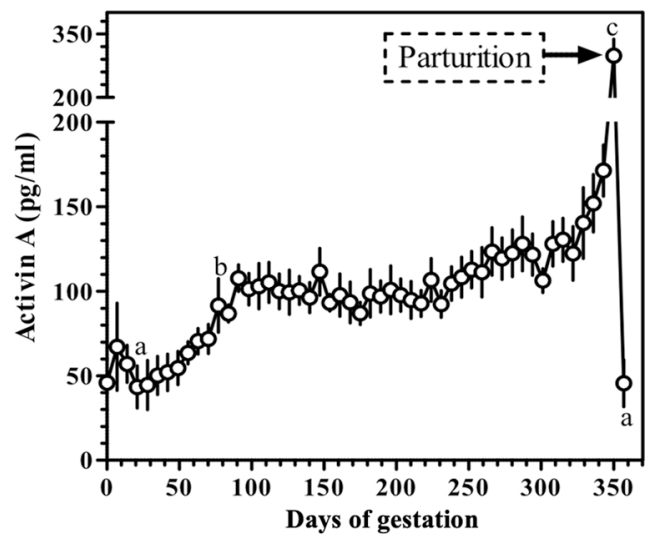

Fig. 2. Plasma concentrations of activin A in mares during gestation, on the day of parturition, and one week after parturition. Data were normalized to the day of mating (Day 0 ) in the fertile cycle and to the day of parturition. Different letters indicate significant differences at $P<0.001$. Each value represents the mean \pm S.E.M. of six mares.

Table 1. Results of immunostaing of equine fetal ovary, placental tissue for activin receptors (IA, IB, IIA, IIB), and their intracellular mediators (Smad2, Smad3, Smad4)

\begin{tabular}{|c|c|c|c|c|c|c|c|c|}
\hline & \multirow{2}{*}{ Fetal age } & \multicolumn{4}{|c|}{ Activin receptor } & \multicolumn{3}{|c|}{ Intracellular mediator } \\
\hline & & IA & IB & IIA & IIB & Smad2 & Smad3 & Smad4 \\
\hline \multicolumn{9}{|l|}{ Fetal ovary } \\
\hline \multirow[t]{4}{*}{ Germ cell } & 110 & + & + & + & + & + & + & + \\
\hline & 140 & + & + & + & + & + & + & + \\
\hline & 180 & + & + & + & + & + & + & + \\
\hline & 270 & + & + & + & + & + & + & + \\
\hline \multirow[t]{4}{*}{ Interstitial cell } & 110 & + & + & + & + & + & + & + \\
\hline & 140 & + & + & + & + & + & + & + \\
\hline & 180 & + & + & + & + & + & + & + \\
\hline & 270 & + & + & + & + & + & + & + \\
\hline \multicolumn{9}{|l|}{ Placental tissue } \\
\hline \multirow[t]{4}{*}{ Trophoblast } & 110 & + & + & + & + & + & + & + \\
\hline & 140 & + & + & + & + & + & + & + \\
\hline & 180 & + & + & + & + & + & + & + \\
\hline & 270 & + & + & + & + & + & + & + \\
\hline \multirow[t]{4}{*}{ Uterine gland } & 110 & + & + & + & + & + & + & + \\
\hline & 140 & + & + & + & + & + & + & + \\
\hline & 180 & + & + & + & + & + & + & + \\
\hline & 270 & + & + & + & + & + & + & + \\
\hline \multirow[t]{4}{*}{ Endometrial stroma } & 110 & + & + & + & + & + & + & + \\
\hline & 140 & + & + & + & + & + & + & + \\
\hline & 180 & + & + & + & + & + & + & + \\
\hline & 270 & + & + & + & + & + & + & + \\
\hline
\end{tabular}

Immunolabeling was scored as follows: - no immunolabeling; + immunolabeling above background.

not change throughout the period of gestation examined (Table 1). Sertoli cells of the fetal testis at 120, 180, 225, and 314 days of gestation were immunostained with activin receptors IB and IIB; however, activin receptors IA and IIA 
Table 2. Results of immunostaing of equine fetal testis, placental tissue for activin receptors (IA, IB, IIA, IIB), and their intracellular mediators (Smad2, Smad3, Smad4)

\begin{tabular}{|c|c|c|c|c|c|c|c|c|}
\hline & \multirow{2}{*}{ Fetal age } & \multicolumn{4}{|c|}{ Activin receptor } & \multicolumn{3}{|c|}{ Intracellular mediator } \\
\hline & & IA & IB & IIA & IIB & Smad2 & Smad3 & Smad4 \\
\hline \multicolumn{9}{|l|}{ Fetal testis } \\
\hline \multirow[t]{4}{*}{ Germ cell } & 120 & + & + & + & + & - & + & - \\
\hline & 180 & + & + & + & + & - & + & - \\
\hline & 225 & + & + & + & + & + & + & - \\
\hline & 314 & + & + & + & + & + & - & - \\
\hline \multirow[t]{4}{*}{ Sertoli cell } & 120 & - & + & - & + & - & + & - \\
\hline & 180 & - & + & - & + & - & + & - \\
\hline & 225 & - & + & - & + & - & + & - \\
\hline & 314 & - & + & - & + & - & + & - \\
\hline \multirow[t]{4}{*}{ Interstitial cell } & 120 & + & + & + & + & + & + & + \\
\hline & 180 & + & + & + & + & + & + & + \\
\hline & 225 & + & + & + & + & + & + & + \\
\hline & 314 & + & + & + & + & + & + & + \\
\hline \multicolumn{9}{|l|}{ Placental tissue } \\
\hline \multirow[t]{4}{*}{ Trophoblast } & 120 & + & + & + & + & + & + & + \\
\hline & 180 & + & + & + & + & + & + & + \\
\hline & 225 & + & + & + & + & + & + & + \\
\hline & 314 & + & + & + & + & + & + & + \\
\hline \multirow[t]{4}{*}{ Uterine gland } & 120 & + & + & + & + & + & + & + \\
\hline & 180 & + & + & + & + & + & + & + \\
\hline & 225 & + & + & + & + & + & + & + \\
\hline & 314 & + & + & + & + & + & + & + \\
\hline \multirow[t]{4}{*}{ Endometrial stroma } & 120 & + & + & + & + & + & + & + \\
\hline & 180 & + & + & + & + & + & + & + \\
\hline & 225 & + & + & + & + & + & + & + \\
\hline & 314 & + & + & + & + & + & + & + \\
\hline
\end{tabular}

Immunolabeling was scored as follows: - no immunolabeling; + immunolabeling above background.

were not immunostained (Table 2).

Immuno-positive staining of activin receptors IA, IB, IIA, and IIB was observed in trophoblast cells, uterine glands, and endometrial stromal cells of pregnant mares carrying female fetuses $(110,140,180$, and 270 days of gestation; Table 1). This was also true in pregnant mares carrying male fetuses (120, 180, 225, and 314 days of gestation; Table 2).

\section{Immuno-localization of activin intracellular mediators Smad2, Smad3 and Smad4}

All three types of activin intracellular mediators, i.e., Smad2, Smad3, and Smad4, were immunolocalized in germ cells and interstitial cells of the fetal ovary at 110, 140, 180, and 270 days of gestation (Table 1). On the other hand, the germ cells in the fetal testis at 120, 180, 225, and 314 days of gestation were not immunostained with Smad4 (Table 2 ). In Sertoli cells of the fetal testis at 120, 180, 225, and 314 days of gestation, neither the Smad2 nor Smad4 type of activin intracellular mediators was immunostained. In interstitial cells of the fetal testes, the three types of Smads were immunolocalized at all stages of pregnancy, i.e., at $120,180,225$, and 314 days of gestation (Table 2).

Immuno-positive staining of Smad2, Smad3, and Smad4 was observed in trophoblast cells, uterine glands, and endometrial stromal cells of pregnant mares carrying female fetuses $(110,140,180$, and 270 days of gestation; Tables 1 and 2). This was also true in pregnant mares carrying male fetuses (120, 180, 225, and 340 days of gestation). The staining was completely absent in the control sections of these tissues.

\section{Discussion}

In the present study, our hypothesis that activins belonging to TGF- $\beta$ family could be candidates for the cause of the enlargement of equine fetal gonads was investigated with the following two experiments. In the first experiment, the plasma concentrations of activin A in pregnant mares were characterized. In the second experiment, equine fetal gonads and utero-placental tissues were immunohistochemically 


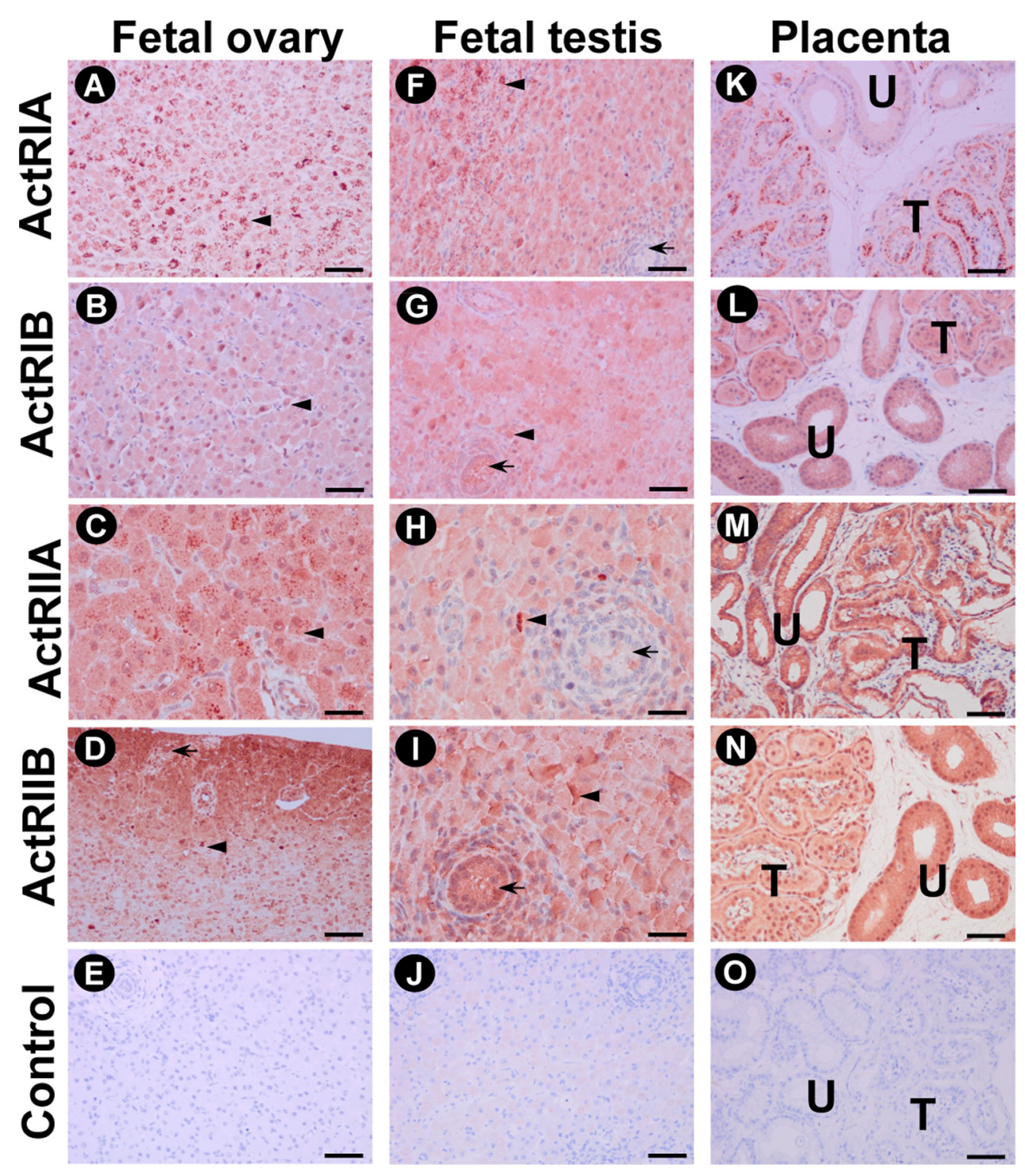

Fig. 3. Photomicrographs of histological sections of the equine fetal ovary ( 180 days of gestation), fetal testis ( 180 days of gestation), and placenta (180 days of gestation). Tissue sections were stained with hematoxylin and eosin. Tissue sections incubated with antibodies to activin receptors for IA (ActRIA; A, F, and K), IB (ActRIB; B, G, and L), IIA (ActRIIA; C, H, and M), and IIB (ActRIIB; D, I, and N) are shown. Negative control sections for immunohistochemistry are also shown (E, J, and O). Arrow, germ cells; arrowhead, interstitial cells; $\mathrm{U}$, uterine gland; $\mathrm{T}$, trophoblast cell. $\mathrm{Bar}=50 \mu \mathrm{m}$.

analyzed for four types of activin receptors and three types of intracellular mediators. The results of the first experiment clearly showed that the concentrations of activin A in maternal circulation remained low until four weeks of gestation, thereafter, started to increase, and peaked first at 11 weeks of gestation. Thereafter, a second remarkable peak of circulating activin A was observed on the day of parturition. There has previously been no information available on the circulating status of activin in mares during gestation. Thus, the changes of circulating activin A levels in pregnant mares were characterized for the first time in the present study.
In the second experiment, the results clearly demonstrated that four activin receptors, i.e., IIA, IIB, IA, and IB, and their three intracellular mediators, i.e., Smad2, Smad3, and Smad4, were immunolocalized in the fetal gonad and uteroplacental tissues of the pregnant mares from 110 to 314 days of gestation. This is the first report to focuses on the demonstration of activin receptors and cytoplasmic coactivators proteins in equine fetal gonads. Supporting the present results, a previous paper also demonstrated that all four isoforms of activin receptor were expressed in the uteroplacental tissues, including the endometrial epithelium, 

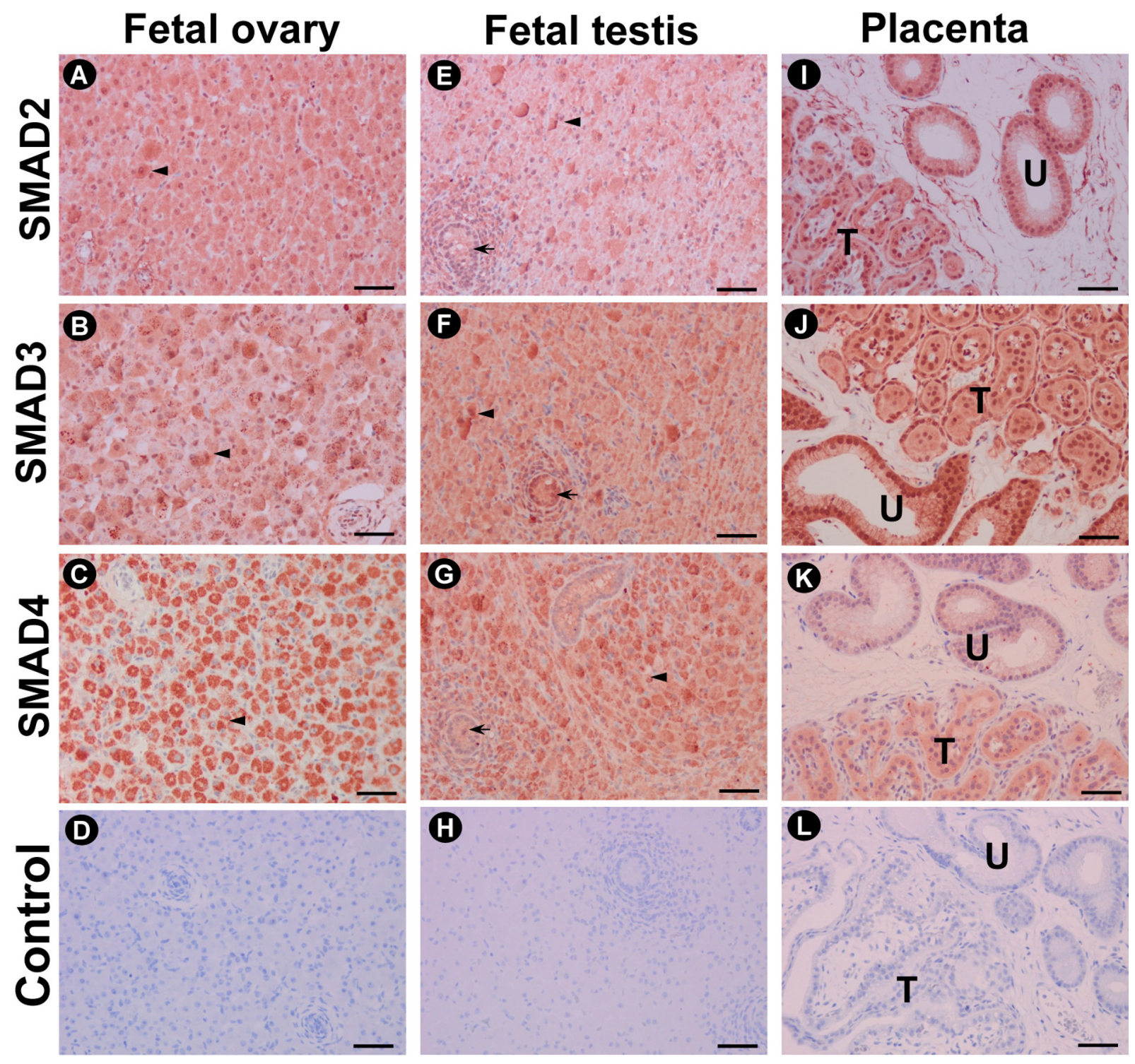

Fig. 4. Immunolocalization of the different Smads (SMAD2; A, E, and I), (SMAD3; B, F, and J), (SMAD4; C, G, and K) in the fetal ovary (180 days of gestation), fetal testis (180 days of gestation), and placenta (180 days of gestation) along with their respective controls (D, H, and L). Arrow, germ cells; arrowhead, interstitial cells; U, uterine gland; T, trophoblast cell. Bar=50 $\mu \mathrm{m}$.

uterine glands, trophoblasts, and myometrium, throughout gestation in mares [14]. In addition, contrary to our previous findings [2] showing that the activin A concentrations in fetal gonads were low, high levels of activin A were detected in maternal endometrial tissues and fetal placental tissues. Our previous study also showed that the concentration of activin A in maternal endometrial tissues was significantly higher than that in fetal placental tissues [2].

The equine uterine glands, but not the trophoblast cells, express mRNA for activin/inhibin $\beta$ A subunit [43], and this protein has been confirmed to be immunolocalized $[2,44]$ in the same tissue. Activin A levels in placental/ endometrial homogenates followed a similar pattern of fetal gonadal enlargement and regression, pointing at a possible physiological role of activin, such as the up-regulation of LH and FSH receptors, and stimulation of secretion of FSH and gonadal hormones, behind this mechanism of the fetal gonads [2]. These previous results demonstrated the activinproducing capacity of the maternal uterus and placenta. In addition, the present results evidenced the existence of activin receptors and functional signaling molecules in these organs. The present study, together with our previous study [2], revealed that the maternal uterus is a major source of activin. Furthermore, the placental tissue is also a source 
of activin during equine gestation. The first increment in activin A level in maternal circulation and utero-placental homogenates coinciding with the timing of initiation of fetal gonadal enlargement suggests that activin from uteroplacental tissues may have a stimulatory role in fetal gonad enlargement and utero-placental development in mares. On the other hand, the second sharp increase of activin A in the maternal circulation on the day of parturition could be important to follicular development in the maternal ovary for foal heat through stimulation of FSH secretion from the anterior pituitary gland and upregulation of $\mathrm{LH}$ and FSH receptors in the maternal ovary.

The fetal gonads of the horses are unique in that they gradually increase in size from around day 100 of gestation to their maximum size at day 250 of gestation, subsequently regressing towards the end of gestation [6]. The fetal testis [35] and ovary [34] stain positively for inhibin/activin $\beta \mathrm{A}$ subunit. A previous study also reported that the inhibin A concentrations in homogenates of fetal gonadal tissues and the fetal circulation were very high as compared with the respective maternal samples, whereas the activin A concentrations in the fetal gonads were undetectable [2]. This clearly indicates that the $\beta$ A subunit produced by the fetal gonads is in the form of inhibin A, without the formation of activin $A$. If there is an activin signaling mechanism in the fetal gonads, the source of the activin is likely extragonadal.

The present study characterized the circulating activin A concentrations in pregnant mares during gestation and a week after parturition. Circulating activin A concentrations significantly increased at around 80 days of gestation. This coincides with the period just prior to initiation of the enlargement of the fetal gonads [4]. The intra-gonadal and endocrine roles of activin have been demonstrated in primates [30], sheep [13], rats [22], golden hamsters [26], and chickens [32], which showed the differential roles of activin, such as germ cell development [19]; hypothalamic, pituitary, and gonadal hormone secretion [16, 23]; and upregulation of LH and FSH receptors [9, 15, 25]. The present results show that the fetal gonads express all forms of activin receptors and Smads required for the intracellular mediation of activin signaling at all the stages of development, suggesting the possibility of activin action in the developing fetal gonads. The present study suggests that elevated activin A may increase FSH and LH receptors in the fetal gonads, resulting in gonadal development in the presence of the low but unchanging levels of FSH and LH. The first significant increase in the circulating activin A concentration in pregnant mares also coincides with some critical events of placentation in equines. The equine embryo takes a considerably long time (40 days) to attach to the uterus [33]. The complex micro-cotyledon formation of the equine placenta completes gradually over
75-100 days [33]. The equine placenta forms endometrial cups that secrete equine chorionic gonadotropin (eCG) [1, 7]. The peak of eCG is at around 80 days [11], which is also the time at which the activin A concentration peaked in the pregnant mares in the present study. This leads to the suggestion that activin A promotes eCG secretion from the endometrial cups. Evidence from human placental cells [29] indicates that activin regulates the secretion of human chorionic gonadotropin (hCG) and gonadotropin-releasing hormone $(\mathrm{GnRH})$. Similar phenomena could be anticipated with respect to the elevated activin A at around 80 days of gestation in mares. Supporting the present results, our previous study clearly demonstrated that all four isoforms of activin receptors were expressed in the utero-placental tissues, including the endometrial epithelium, uterine glands, trophoblasts, and myometrium, throughout equine gestation [14]. These results suggested the potential role of activin in the utero-placental tissues in pregnant mares [14]. The receptors for the activins and their intracellular mediators, Smads, were immunostained in utero-placental tissues of mares in the present study from as early as 110 days through to 314 days of gestation. The immunostaining was evident in both the uterine glands and trophoblast cells. The present study, together with our previous study [2], suggests that activins may be involved in the regulation of hormone secretion from the equine placenta, as well as in the development of the placenta in an autocrine and paracrine fashion. Previous papers reported that activin receptors are expressed in the endometrial epithelium, uterine glands, and trophectoderm in ewes [10] and rats [5].

The circulating activin A concentrations in the pregnant mares were at a fairly constant level after 80 days of gestation until 250 days of gestation. On the day of parturition, the circulating activin A concentration showed a sharp, significant increase. At the time of parturition, an increase in basal levels of FSH has been reported in pregnant mares $[12,38]$. Ginther [6] suggested that this FSH increase may be related to either the removal of inhibitory influences from the feto-placental unit or the hormonal changes that initiated parturition. Contrarily, high amounts of inhibin are secreted by the fetal gonads [34, 35], and the gonadal size decreases almost tenfold [4] as parturition nears, thereby causing a sharp drop in circulatory inhibin levels in mares. The inhibitory function of inhibin on FSH secretion [21, 40] is thus removed, thereby allowing FSH to increase. Mares exhibit foal heat, which begins 5-12 days after foaling [8]. Alternatively, the present results indicate that another factor, activin, stimulates the FSH secretion ultimately responsible for foal heat. Activin stimulates FSH secretion from the pituitary gland [39] and also stimulates the production of FSH and LH receptors in the granulosa cells in ovarian follicles of the maternal ovaries [15]. The present results suggest that 
the surge of activin A on the day of parturition in mares may be responsible for the FSH surge observed at the same time of gestation in earlier studies [12, 38]. A previous study on human gestation [31] showed that activin A levels increase during pre-eclamptic parturitions, indicating a relationship between activin A and increased gestation labor. The activin A surge in the parturient mares in the present study was not associated with such a possibility, as all the mares foaled normally. This further supports our hypothesis that activin A in peri-parturient mares could be important for foal heat. Further detailed studies are warranted to prove this hypothesis.

In conclusion, the present study characterized the circulating activin A concentrations during gestation in mares along with possible endocrinological associations to the significant increments in the concentrations of activin A. Furthermore, this study evidenced the biological machinery required for activin signaling in the equine fetal gonads and utero-placental tissues during gestation.

\section{References}

1. Allen, W.R., and Moor, R.M. 1972. The origin of the equine endometrial cups. I. Production of PMSG by fetal trophoblast cells. J. Reprod. Fertil. 29: 313-316. [Medline] [CrossRef]

2. Arai, K.Y., Tanaka, Y., Taniyama, H., Tsunoda, N., Nambo, Y., Nagamine, N., Watanabe, G., and Taya, K. 2006. Expression of inhibins, activins, insulin-like growth factor-I and steroidogenic enzymes in the equine placenta. Domest. Anim. Endocrinol. 31: 19-34. [Medline] [CrossRef]

3. Chen, Y.G., Wang, Q., Lin, S.L., Chang, C.D., Chuang, J., and Ying, S.Y. 2006. Activin signaling and its role in regulation of cell proliferation, apoptosis, and carcinogenesis. Exp. Biol. Med. (Maywood) 231: 534-544. [Medline] [CrossRef]

4. Cole, H.H., Hart, G.H., Lyons, W.R., and Catchpole, H.R. 1933. The development and hormonal content of fetal horse gonads. Anat. Rec. 56: 275-293. [CrossRef]

5. Debiève, F., Hinck, L., Biard, J.M., Bernard, P., and Hubinont, C. 2006. Activin receptor expression and induction of apoptosis in rat blastocysts in vitro. Hum. Reprod. 21: 618-623. [Medline] [CrossRef]

6. Ginther, O.J. 1992. Embryology and placentation. pp. 345-417. In: Reproductive Biology of the Mare-basic and Applied Aspects, Equiservices, Madison.

7. Ginther, O.J. 1992. Endocrinology of pregnancy. pp. 419-456. In: Reproductive Biology of the Mare-basic and Applied Aspects, Equiservices, Madison.

8. Ginther, O.J. 1992. Parturition, pierperium and puberty. pp. 457-497. In: Reproductive Biology of the Mare-basic and Applied Aspects, Equiservices, Madison.

9. Hasegawa, Y., Miyamoto, K., Abe, Y., Nakamura, T., Sugino, H., Eto, Y., Shibai, H., and Igarashi, M. 1988.
Induction of follicle stimulating hormone receptor by erythroid differentiation factor on rat granulosa cell. Biochem. Biophys. Res. Commun. 156: 668-674. [Medline] [CrossRef]

10. Hayashi, K., Carpenter, K.D., Gray, C.A., and Spencer, T.E. 2003. The activin-follistatin system in the neonatal ovine uterus. Biol. Reprod. 69: 843-850. [Medline] [CrossRef]

11. Hoppen, H.O. 1994. The equine placenta and equine chorionic gonadotrophin-an overview. Exp. Clin. Endocrinol. 102: 235-243. [Medline] [CrossRef]

12. Irvine, C.H., and Evans, M.J. 1978. FSH and LH concentrations preceding post-partum ovulation in the mare. $N$. Z. Vet. J. 26: 310-311. [Medline] [CrossRef]

13. Jarred, R.A., Cancilla, B., Richards, M., Groome, N.P., McNatty, K.P., and Risbridger, G.P. 1999. Differential localization of inhibin subunit proteins in the ovine testis during fetal gonadal development. Endocrinology 140: 979-986. [Medline] [CrossRef]

14. Kimura, Y., Sasaki, M., Watanabe, K., Dhakal, P., Sato, F., Taya, K., and Nambo, Y. 2018. Expression of activin receptors in the equine uteroplacental tissue: an immunohistochemical analysis. J. Equine Sci. 29: 33-37. [Medline] [CrossRef]

15. Li, R., Phillips, D.M., and Mather, J.P. 1995. Activin promotes ovarian follicle development in vitro. Endocrinology 136: 849-856. [Medline] [CrossRef]

16. Lin, T., Calkins, J.K., Morris, P.L., Vale, W., and Bardin, C.W. 1989. Regulation of Leydig cell function in primary culture by inhibin and activin. Endocrinology 125 : 2134-2140. [Medline] [CrossRef]

17. Ling, N., Ying, S.Y., Ueno, N., Shimasaki, S., Esch, F., Hotta, M., and Guillemin, R. 1986. A homodimer of the beta-subunits of inhibin A stimulates the secretion of pituitary follicle stimulating hormone. Biochem. Biophys. Res. Commun. 138: 1129-1137. [Medline] [CrossRef]

18. Mabuchi, Y., Yamoto, M., Minami, S., and Umesaki, N. 2006. The autocrine effect of activin A on human ovarian clear cell adenocarcinoma cells. Oncol. Rep. 16: 373-379. [Medline]

19. Mather, J.P., Attie, K.M., Woodruff, T.K., Rice, G.C., and Phillips, D.M. 1990. Activin stimulates spermatogonial proliferation in germ-Sertoli cell cocultures from immature rat testis. Endocrinology 127: 3206-3214. [Medline] [CrossRef]

20. Mathews, L.S. 1994. Activin receptors and cellular signaling by the receptor serine kinase family. Endocr. Rev. 15: 310-325. [Medline] [CrossRef]

21. Medan, M.S., Arai, K.Y., Watanabe, G., and Taya, K. 2007. Inhibin: Regulation of reproductive function and practical use in females. Anim. Sci. J. 78: 16-27. [CrossRef]

22. Meehan, T., Schlatt, S., O'Bryan, M.K., de Kretser, D.M., and Loveland, K.L. 2000. Regulation of germ cell and Sertoli cell development by activin, follistatin, and FSH. Dev. Biol. 220: 225-237. [Medline] [CrossRef] 
23. Miró, F., Smyth, C.D., and Hillier, S.G. 1991. Development-related effects of recombinant activin on steroid synthesis in rat granulosa cells. Endocrinology 129: 3388-3394. [Medline] [CrossRef]

24. Nagamine, N., Nambo, Y., Nagata, S., Nagaoka, K., Tsunoda, N., Taniyama, H., Tanaka, Y., Tohei, A., Watanabe, G., and Taya, K. 1998. Inhibin secretion in the mare: localization of inhibin $\alpha$, betaA, and betaB subunits in the ovary. Biol. Reprod. 59: 1392-1398. [Medline] [CrossRef]

25. Nakamura, M., Minegishi, T., Hasegawa, Y., Nakamura, K., Igarashi, S., Ito, I., Shinozaki, H., Miyamoto, K., Eto, Y., and Ibuki, Y. 1993. Effect of an activin A on follicle-stimulating hormone ( $\mathrm{FSH})$ receptor messenger ribonucleic acid levels and FSH receptor expressions in cultured rat granulosa cells. Endocrinology 133: 538-544. [Medline] [CrossRef]

26. Ohshima, K., Ohshima, K., Arai, K.Y., Kishi, H., Itoh, M., Watanabe, G., Terranova, P.F., Arai, K., Uehara, K., Groome, N.P., and Taya, K. 2002. Potential role of activin $\mathrm{A}$ in follicular development during the second half of pregnancy in the golden hamster: utero-placental source of activin A. J. Endocrinol. 172: 247-253. [Medline] [CrossRef]

27. Pangas, S.A., and Woodruff, T.K. 2000. Activin signal transduction pathways. Trends Endocrinol. Metab. 11: 309-314. [Medline] [CrossRef]

28. Pashen, R.L., and Allen, W.R. 1979. The role of the fetal gonads and placenta in steroid production, maintenance of pregnancy and parturition in the mare. J. Reprod. Fertil. Suppl. 27: 499-509. [Medline]

29. Petraglia, F., Vaughan, J., and Vale, W. 1989. Inhibin and activin modulate the release of gonadotropin-releasing hormone, human chorionic gonadotropin, and progesterone from cultured human placental cells. Proc. Natl. Acad. Sci. USA 86: 5114-5117. [Medline] [CrossRef]

30. Rabinovici, J., Goldsmith, P.C., Roberts, V.J., Vaughan, J., Vale, W., and Jaffe, R.B. 1991. Localization and secretion of inhibin/activin subunits in the human and subhuman primate fetal gonads. J. Clin. Endocrinol. Metab. 73: 1141-1149. [Medline] [CrossRef]

31. Reddy, A., Suri, S., Sargent, I.L., Redman, C.W.G., and Muttukrishna, S. 2009. Maternal circulating levels of activin A, inhibin A, sFlt-1 and endoglin at parturition in normal pregnancy and pre-eclampsia. PLoS One 4: e4453. [Medline] [CrossRef]

32. Safi, M., Onagbesan, O.M., Volckaert, G., Vanmontfort, D., Bruggeman, V., and Decuypere, E. 2001. Developmental expression of activin/inhibin alpha- and beta(A)-subunit genes in the gonads of male and female chick embryos. Gen. Comp. Endocrinol. 122: 304-311. [Medline] [CrossRef]

33. Samuel, C.A., Allen, W.R., and Steven, D.H. 1974. Studies on the equine placenta. I. Development of the microcotyledons. J. Reprod. Fertil. 41: 441-445. [Medline] [CrossRef]
34. Tanaka, Y., Taniyama, H., Tsunoda, N., Herath, C.B., Nakai, R., Shinbo, H., Nagamine, N., Nambo, Y., Nagata, S., Watanabe, G., Groome, N.P., and Taya, K. 2003. Localization and secretion of inhibins in the equine fetal ovaries. Biol. Reprod. 68: 328-335. [Medline] [CrossRef]

35. Tanaka, Y., Taniyama, H., Tsunoda, N., Shinbo, H., Nagamine, N., Nambo, Y., Nagata, S., Watanabe, G., Herath, C.B., Groome, N.P., and Taya, K. 2002. The testis as a major source of circulating inhibins in the male equine fetus during the second half of gestation. J. Androl. 23: 229-236. [Medline]

36. Tsuchida, K., Sawchenko, P.E., Nishikawa, S., and Vale, W.W. 1996. Molecular cloning of a novel type I receptor serine/threonine kinase for the TGF beta superfamily from rat brain. Mol. Cell. Neurosci. 7: 467-478. [Medline] [CrossRef]

37. Tsunoda, N., Machida, N., Nagata, S.I., Nagamine, N., Nambo, Y., Oikawa, M., Taniyama, H., Watanabe, G., and Taya, K. 1996. A morphometric study of interstitial cells in equine fetal gonads. J. Reprod. Dev. 42: j91-j95. [CrossRef]

38. Turner, D.D., Garcia, M.C., Miller, K.F., Holtan, D.W., and Ginther, O.J. 1979. FSH and LH concentrations in periparturient mares. J. Reprod. Fertil. Suppl. 27: 547-553. [Medline]

39. Vale, W., Rivier, C., Hsueh, A., Campen, C., Meunier, H., Bicsak, T., Vaughan, J., Corrigan, A., Bardin, W., Sawchenko, P., Petraglia, F., Yu, J., Plotsky, P., Spiess, J., and Rivier, J. 1988. Chemical and biological characterization of the inhibin family of protein hormones. Recent Prog. Horm. Res. 44: 1-34. [Medline]

40. Vale, W., Rivier, J., Vaughan, J., McClintock, R., Corrigan, A., Woo, W., Karr, D., and Spiess, J. 1986. Purification and characterization of an FSH releasing protein from porcine ovarian follicular fluid. Nature 321: 776-779. [Medline] [CrossRef]

41. Wrana, J.L., Attisano, L., Wieser, R., Ventura, F., and Massagué, J. 1994. Mechanism of activation of the TGF-beta receptor. Nature 370: 341-347. [Medline] [CrossRef]

42. Xia, Y., and Schneyer, A.L. 2009. The biology of activin: recent advances in structure, regulation and function. $J$. Endocrinol. 202: 1-12. [Medline] [CrossRef]

43. Yamanouchi, K., Hirasawa, K., Hasegawa, T., Ikeda, A., Chang, K.T., Matsuyama, S., Nishihara, M., Miyazawa, K., Sawasaki, T., Tojo, H., Tachi, C., and Takahashi, M. 1997. Equine inhibin/activin beta A-subunit mRNA is expressed in the endometrial gland, but not in the trophoblast, during pregnancy. Mol. Reprod. Dev. 47: 363-369. [Medline] [CrossRef]

44. Zhang, H., Nagaoka, K., Imakawa, K., Nambo, Y., Watanabe, G., Taya, K., and Weng, Q. 2013. Expression of inhibin/activin subunits in the equine uteri during the early pregnancy. Reprod. Domest. Anim. 48: 423-428. [Medline] [CrossRef] 